\title{
Assessing the Impact of the Thailand-European Union Free Trade Agreement on Trade and Investment in Thailand
}

\author{
Inthira Yamabhai ${ }^{1,2^{*}}$, Benjarin Santatiwongchai ${ }^{2}$ and Chutima Akaleephan ${ }^{1}$ \\ 1 International Trade and Health Programme, International Health Policy Program, Ministry of Public Health, Nonthaburi, Thailand \\ ${ }^{2}$ Health Intervention and Technology Assessment Program (HITAP), Ministry of Public Health, Nonthaburi, Thailand
}

\begin{abstract}
This study investigated the role of the Generalized System of Preference (GSP) from the EU on Thai exports and the implications of an EU FTA on trade and investment in Thailand. The findings indicated that Thai exporters did not maximize the use of the GSP as their exports under the system amounted to $63 \%$ of GSP eligible goods. The OLS regressions failed to observe any significant role the GSP had on Thai exports. From international experience, fixed and random effects models suggested that signing an FTA was not a significant determinant of exports to the EU and obtaining investments from the EU.
\end{abstract}

Keywords: Health economics; Generalized system of preference; European Union; EU free trade agreement

\section{Introduction}

In the last few decades, the economy in Asia has shown rapid growth. As a result, many high income countries initiated bilateral trade agreements with countries in the region. One such example is the European Union (EU) initiating negotiations of the EU free trade agreement (FTA) with the Association of Southeast Asian Nations (ASEAN) in 2007. However, after 9 rounds, the negotiations could not be concluded and was suspended in 2009. After some time passed, the EU reconsidered starting bilateral agreement negotiations with countries in Asia again. The first country in Asia to sign an FTA with EU was South Korea, an EU major non-European trade partner with significant market potential [1]. This agreement entered into force in 2011.

For the South East Asia region, the FTA negotiations between the $\mathrm{EU}$ and Singapore were completed in 2014. Singapore is the biggest EU trade partner in ASEAN and the gateway to South East Asia, in addition to being home to many European companies' regional headquarters. Moreover, Singapore's main export product is not a politically sensitive product, e.g. agricultural products. In its attempts to expand FTA agreements to other countries in the region, the EU has ongoing negotiations with many countries, including Malaysia, Vietnam, and Thailand.

The EU is an important trade partner for Thailand. In 2012, the value of exports from Thailand to the EU was 21.8 billion USD, which accounted for $9.5 \%$ of Thailand's total export value [2]. Previously, Thailand - as a lower-middle-income country - was granted trade support by the EU in the form of the Generalized System of Preference (GSP) tariff system. The GSP granted by the EU offered Thailand a zero tariff rate for non-sensitive goods and lowered tariff rates for sensitive goods. However, since Thailand was classified by the World Bank as an upper-middle-income country in 2010, Thailand is no longer eligible for the benefits of the EU's GSP, and the privilege was subsequently withdrawn in 2015. The withdrawal affected 723 goods and Thailand's trade competitiveness in the EU market, which would definitely decrease compared to other EU trade partners in the South East Asia region that continue to be eligible for the GSP. The direct monetary impact of the withdrawal is estimated to be 142 million USD while the total impact including indirect effects from decreased competitiveness is estimated to be 1,080 million USD [3].
An option for Thailand to compensate for the loss in competitiveness is to sign an FTA with the EU, with the expectation that the FTA would decrease the import tax to all products in the long-run, yielding a lower or equal tax rate to the GSP's rate. However, while the FTA negotiations between the EU and Thailand started in 2013, it has yet to be completed due to the political situation in the country.

The objective of an FTA is to promote trade and investment between trade partners. As such, it is a tool to enhance the competitiveness of a country in a certain market. Barriers between trade partners will be lowered for both trade and investment, and further facilitate trade between the partners. On the other hand, the easier access to a trade partner's market implies that the degree of competition will be higher for local entrepreneurs. Previous literatures have shown support for FTAs with the EU, suggesting that it would stimulate trade and benefit to Chile, South Korea, and Thailand [4-6]. However, those studies were also conducted and used data before the 2008 economic crisis was occurred [7].

As a result, the impact of an FTA on the Thai economy is difficult to predict. Nevertheless, Thailand can learn from the lessons of other countries that have signed FTAs with the EU to see how the Thai-EU FTA will affect trade and investment between the partners. Therefore, this study attempts to assess the role of the GSP and FTA on Thailand and to learn from the experiences of other countries. It examines the trade situation between Thailand and the EU and investigates the factors affecting trade. For countries where the EU FTA has already entered into force, this study will explore whether the FTA is a significant determinant factor which influences trade and investment between EU and those countries and whether the change is positive or negative.

${ }^{*}$ Corresponding author: Inthira Yamabhai, International Trade and Health Programme (ITH), International Health Policy Program (IHPP), Ministry of Public Health, Tiwanon Rd. Nonthaburi 11000, Thailand, Tel: +6625902382, Fax: +6625902385; E-mail: inthira@ihpp.thaigov.net

Received December 05, 2017; Accepted December 18, 2017; Published December 26, 2017

Citation: Yamabhai I, Santatiwongchai B, Akaleephan C (2017) Assessing the Impact of the Thailand-European Union Free Trade Agreement on Trade and Investment in Thailand. Health Econ Outcome Res Open Access S1: 106. doi: 10.4172/2471-268x.1000.S1-106

Copyright: (c) 2017 Yamabhai I, et al. This is an open-access article distributed under the terms of the Creative Commons Attribution License, which permits unrestricted use, distribution, and reproduction in any medium, provided the original author and source are credited. 
The next section examines literature on the role of the EU FTA on trade outcomes while section 3 outlines the data and methodologies. The empirical results are presented in section 4 and the last section discusses the main results, highlighting policy implications as well as how the results can support policy decisions.

\section{Literature Review}

This section provides empirical evidence of the impact of EU FTA on trade between the partner countriesplanning to enter into the negotiations. Every study confirmed the benefits of a EUFTA, indicating that the bilateral agreement would increase trade between the two countries. For example, the EU-Chile FTA was effective in 2000. The Central Bank of Chile used a dynamic stochastic general equilibrium (DSGE model)to estimate the trade impact and found that the EUFTA would increase overall production by $1 \%$ and that overall consumption and welfare would increase in the long-run [8]. When looking specifically at exports, Nowak-Leeman et al. used the extended gravity model comprising data from 1998-2002 and found that the EU FTA would increase fishery exports by $7.4 \%$ while fruit exports would increase by $27 \%$ after a 10 -year transitional period; wine exports would also increase by $21 \%$ by 4 years after the transitional period [ 9 ]. Changes in the same direction were also found from two studies of Jean et al. and Bureau et al., which used Computable general equilibrium (CGE) models to compare trade in 2002 and 2008. The authors found that agricultural products, wine, timber, and seafood products benefited from the agreement. Exports to the EU would increase by $21 \%$ and imports from the EU would increase by $65 \%$ from 2002 to $2008[10,11]$. As a result, GDP would also increase by $0.05 \%$ [11].

The first transatlantic FTA belongs to Mexico, and the agreement came into force in 2000 [12,13]. All EU import tax redemptions were abolished on1 January, 2003 [13]. In Slootmaekers' study, data from 1980-2004 was used to estimate the impact of the EU-Mexico FTA using the standard gravity model; it found that exports to the EU would increase by $38 \%$ compared to not having an FTA at all [14].

With a drawn-out negotiation process, the EU-South Korea FTA concluded in 2009 and came into effect in 2011. Francois et al. used a GTAP database and CGE model for their study. With different scenarios depending on the degree of openness, South Korea's real income would increase between $0.58 \%$ and $2.32 \%$, with exports increasing by $36 \%$ [5]. In another study, Bruess and Francois employed a CGE using the GTAP8 database and concluded that South Korea would increase exports to the EU by 23 billion USD [15].

Descriptive statistics in Assarsonand Swain's study showed a75\% increase in exports to the EU and a 93\% increase in imports from the EU [16]. Another simulation conducted by Jachia and Teljeur estimated that exports would increase by $0.9 \%$ of exports in 1996 . Export products that were shown to have benefited from the FTA were fruits, metals, and garments. It was also estimated that South Africa would increase imports from the EU by $2.3 \%$, especially for machinery and chemical products [17].

For assessing the impact of an EU FTA on South Africa, two studies reviewed led to a different conclusion. Kalaba et al. investigated the implications of the EU import tax reduction by using OLS and the results suggested that between 2000 and 2003, the exports value to the EU increased but when compared to overall global exports, the proportion of exports to EU compared with the rest of the World declined from $31 \%$ to $30.8 \%$. Exports under the tax benefit category was found to have decreased from $41 \%$ to $39 \%$ [18]. In another study,
Gay and Nieuwoudt estimated the impact on the orange industry using a trade simulation model from 1997-2011. The results showed that after the FTA, prices of oranges increased less than inflation, i.e. the prices of oranges decreased [19].

For countries where FTAs with the EU were still under negotiations at the time, the empirical evidence suggested that those countries should proceed with the FTA. India has a competitive advantage for garment and clothes. Being granted access to the EU market via a lower import tax than other trading partners would attract more foreign investors to invest in India, resulting in eventual mutual economic benefits. Another study that used CGE and gravity models attempted to estimate the impact of the FTA and found that both countries would benefit from increased national income and local production [20,21]. Decreux and Mitaritonna (2007) found that India's welfare would decrease if trade barriers were reduced by $10 \%$ but would increase if trade barriers decrease by $25 \%$; meanwhile, the EU would benefit from both situations. Although exports to the EU would increase by $13 \%$ in 2020 , it is expected that the benefits would mainly come from the weakened Indian currency instead of the tax benefits due to the trade negotiations [22].

Taking Ukraine as another example, negotiations with the EU on the FTA began in 2008 and the terms were agreed upon in 2011. However, it is still not in effect. Frey and Oleksey et al. estimated that exports to the EU would increase between $1.1 \%$ and $2 \%$ using a CGE model and data at 2007. When looking specifically at industries, the agriculture industry was found to have benefitted from the FTA $[23,24]$.

In Thailand's case, a previous study on the impact of an ASEANEU FTA suggested that Thailand would receive positive benefits for consumer goods, electronics, and vehicles; on the other hand, rubber, leather, and wood products would be affected negatively $[21,25,26]$. Another study on the impact of a Thai-EU FTA on Thailand's GDP, trade, and production disseminated by the Department of Trade Negotiations revealed that if neighbor countries, i.e. Malaysia and Vietnam, signed an EUFTA but Thailand did not, Thailand's GDP would decrease by $0.4 \%$ to $4 \%$ but would also have a trade balance surplus for 0.4-0.5 billion USD. If the FTA came into place, Thailand's GDP was estimated to increase by $3 \%$ but would have a balance of trade deficit for 6.7-7.5 billion USD and exports value for vehicles, agricultural products, production of chemical, rubber and agricultural products decrease if the Thai baht strengthened relative to the Euro [4]

The Thailand Development Research Institute (TDRI) showed that a Thai-EU FTA may help expand Thailand's trade and investment in Thailand. Thailand's GDP would increase by $2.37 \%$ and $3.7 \%$ according to each simulated situation [4]. However, the data used in the study was prior to the economic crisis in the EU. Also, Thailand was categorized as an upper middle income country after that incident and the GSP benefit was to be terminated on 1 January 2015. Subsequently, Thailand would be subject to the Most-Favored Nation (MFN) tariff rate beginning the year after the GSP's termination [27]. Therefore, the results might be overestimated.

Overall, most of the studies in the literature review employed econometric models, and the majority of them suggested that having an FTA would benefit the economies of both partner countries. Only the two studies in South Africa that employed actual data after the FTA was enforced found that the FTA might not provide benefits as expected. The same results were found from studying the FTA between South Korea and the EU, where the perspective model estimated that South Korea would gain from the exemption or reduction of tariffs; this would increase exports to the EU by $36 \%$ and increase imports from 
Citation: Yamabhai I, Santatiwongchai B, Akaleephan C (2017) Assessing the Impact of the Thailand-European Union Free Trade Agreement on Trade and Investment in Thailand. Health Econ Outcome Res Open Access S1: 106. doi: 10.4172/2471-268x.1000.S1-106

Page 3 of 10

the EU by $48 \%$ [5]. However, from the real data after the FTA came into force, although South Korea's export value to the EU increased, the proportion of the export in total exports decreased by $8.5 \%$ compared to the previous year. This was due to the economic recession in the EU and contradicted with the econometric study results about the FTA's expected impact in South Korea. Therefore, studies which used updated data to match the current situation and report expected impacts after the trade agreement comes into effect is needed.

\section{Data and Methodology}

This study consists of three main parts. Each part has its own methodology as follows:

\section{Trade situation and trend between Thailand and the EU}

The situation and trend are explored using descriptive statistics. Data on the value of trade for Thailand and the EU was retrieved from the Bank of Thailand, and international databases. The range of data includes value of trade in goods, value of trade in services, and foreign direct investment (FDI) of Thailand in EU countries from 2003 to 2012. The top five industries that have the highest export value to the $\mathrm{EU}$ were selected to estimate the impact of a FTA.

\section{Expected impact of the GSP and FTA on trade between Thailand and the EU}

Thai exporters will have higher costs due to export duty from the absence of the GSP offered by the EU. The top five industries as identified from the previous section were based on export value for the year 2012. The expected increased export duty is calculated as follows:

Incremental cost $=($ MFN rate- GSP rate $) \times$ Export value 2012

Most-favored-nation (MFN) tariff is the tariff rate offered by the EU to other members of the WTO. GSP rate signifies the current tariff rate for Thailand's export to the EU under the program; and Export value 2012 is the value of exports in 2012 for the groups of goods that rank among the top 5 highest exports to the EU in that year.

To measure the magnitude of the various factors that influence the value of export goods from Thailand to the EU, a linear regression model was constructed. Important factors affecting exports were reviewed and it was found that the exchange rate, GDP, GDP per capita, lending rate ratio, GDP price deflator ratio, and joint population are all significant determinants of exports $[14,28,29]$. Additionally, tax benefits and competitive advantages are two factors of interest which should be tested to determine whether they are influential to exports. The analysis was conducted both in terms of total export value and export value of the top five exported product groups and the factors included in the analysis are listed in Table 1. A model of the log export value as a functionof related factors was developed and data was fitted to establish the relationship and effects for each factor, as illustrated below.

The equation was:

$L E X P_{i}=\beta_{0}+\beta_{1}$ GDPgrowth $+\beta_{2} D E L T+\beta_{3} R C A+\beta_{4} E X+\beta_{5}$ Inflat $+\varepsilon_{i}$

While the equation for specific industries $\mathrm{j}$ was constructed as follows:

$L \operatorname{Exp}_{j}=\beta_{0}+\beta_{1} G D P C+\beta_{2} E X+\beta_{3} R C A_{j}+\beta_{4} D E L T_{j}+\varepsilon_{j}$

\section{The Role of FTA on trade and investment of countries where the EUFTA is already in place}

Literature review was conducted to obtain important factors that impact exports in trade services and FDI. The literature suggested that

\begin{tabular}{|c|l|c|}
\hline Factors & \multicolumn{1}{|c|}{ Description } & $\begin{array}{c}\text { Source of } \\
\text { data }\end{array}$ \\
\hline LEXPi & $\begin{array}{l}\text { Natural log of total quarterly export value from Thailand } \\
\text { to the EU for quarter i }\end{array}$ & Eurostat \\
\hline LExpj & $\begin{array}{l}\text { Natural log of quarterly export value from Thailand to the } \\
\text { EU for good jin a trimester (unit) }\end{array}$ & Eurostat \\
\hline $\begin{array}{c}\text { GDP } \\
\text { growth }\end{array}$ & Gross domestic product growth rate of the EU(\%) & OECD \\
\hline GDPC & EU Gross domestic product per capita (\$) & OECD \\
\hline EXrate & Exchange rate from US Dollars to Thai Baht & World bank \\
\hline Inflat & Thai inflation rate (\%) & World bank \\
\hline DELT & $\begin{array}{l}\text { Difference between tariff rates offered by the EU to MFN } \\
\text { countries and Thailand under the GSP (|MFN-GSP|) for } \\
\text { good j }\end{array}$ & $\begin{array}{c}\text { World Trade } \\
\text { Organization }\end{array}$ \\
\hline RCAj & $\begin{array}{l}\text { Relative comparative advantage for good j, comparing } \\
\text { between Thailand's exports to the EU and other ASEAN } \\
\text { countries' exports to the EU }\end{array}$ & $\begin{array}{r}\text { Primary } \\
\text { analysis } \\
\text { using } \\
\text { data from } \\
\text { Eurostat }\end{array}$ \\
\hline
\end{tabular}

Table 1: Factors included in the analysis of factors affecting exports from Thailand to the EU.

GDP and GDP growth are factors that significantly increase FDI as they are the main indicators for market attractiveness [30-32]. In contrast, wages and exchange rates have a negative impact on FDI [30,32]. For factors representing technology development, Koh et al. employed electricity consumption and the number of telephones used in countries as variables and found that these two factors were influential to attracting FDI [33]. Variables were also selected to represent the set of host country determinants of FDI developed by UNCTAD [34]. The selected variables representing policy framework are Political Stability and the Rule of Law index. FDI data were obtained from the WDI database.

Since the study utilizes panel data, the types of regression analyses that appropriately fit the data with minimized biases are the fixed effect and random effect models. The fixed effect model is a model that emphasizes differences between selected countries while paying less attention to countries with specific characteristics which cannot be observed. On the other hand, the random effect model is based on a hypothesis of random variables which influence dependent variables, i.e. it assumes that selected countries are randomized from all countries. To determine which type of analysis is a better fit for the data, the Hausman Test is conducted. The results showed that a fixed effect analysis is more effective than a random one when the null hypothesis - that individual effects and regressors are not correlated-is rejected.

The equations to quantify the impact of factors on trade in goods and services from countries to the EU and on FDI from the EU in the countries were constructed as follows:

$$
\begin{aligned}
& \operatorname{LnEXPG}_{i t}=\beta_{0}+\beta_{1} E R_{i t}+\beta_{2} L E N D_{i t}+\beta_{3} C P I_{i t}+\beta_{4} E U 27+\beta_{5} F T A+\mu_{i}+\varepsilon_{i j} \\
& \operatorname{LnEXPS}_{i t}=\beta_{0}+\beta_{1} G D P C_{i t}+\beta_{2} I N T_{i t}+\beta_{3} F T A_{i t}+\beta_{4} E U 27+\mu_{i}+\varepsilon_{i j} \\
& \operatorname{LnFDI}_{i t}=\beta_{0}+\beta_{1} G D P_{i t}+\beta_{2} E R_{i t}+\beta_{3} T E L_{i t}+\beta_{4} P V_{i t}+\beta_{5} R o L_{i t}+\beta_{6} F T A_{i t}+\mu_{i}+\varepsilon_{i j}
\end{aligned}
$$

Where I signifies country I; t signifies time $t ; \beta_{0}$ is a constant; $\beta_{\mathrm{i}}$ is an estimating coefficient; $\mu$ is a country-specific effect, which is assumed to remain constant through time; and $\varepsilon_{i}$ is an error term. The time variable is also considered to reflect on the export and FDI trends over time.

\section{Results of the Analysis}

\section{Situation analysis}

Considering the import and export values between Thailand and the EU from 2003-2012, it was found that Thailand's import and export 
Citation: Yamabhai I, Santatiwongchai B, Akaleephan C (2017) Assessing the Impact of the Thailand-European Union Free Trade Agreement on Trade and Investment in Thailand. Health Econ Outcome Res Open Access S1: 106. doi: 10.4172/2471-268x.1000.S1-106

values increased overall. The export value from Thailand to the EU was twice as high as the import value, especially in the export of industrial goods. However, the export value growth rate was lower than that of the import value at $6.2 \%$ and $9.8 \%$, respectively [35]. Considering the export values in Figure 1, the ten-year trend suggests that the export value of industrial goods has always been higher than that of agricultural and fisheries products by 13 times on average.

In 2012, exports to the EU was 21 billion USD, which accounted for $28.4 \%$ of Thailand's exports globally. Before the EU's economic recession in 2008, the growth rate of Thailand's exports to the EU was $14 \%$ [35] based on export figures during 2003 to 2008. The overall export value in 2009 was $22 \%$ less than overall exports in 2008 . After the crisis, the exports value increased.

Figure 2 illustrates Thailand's top five export industries, which comprises electronics, processed agricultural products, machinery, automobiles, and jewelry; these are ranked respective of their export value. However, the maximum growth rate was seen in machinery products while electronics group appears to have the lowest growth at 3\%.

However, it was found that in 2012, Thailand exported products eligible for the GSP to the EU at a value of 14 billion USD. However, some exporters did not use their rights, therefore only 8 billion USD of
GSP was exercised [36]. This indicates that Thailand did not use its GSP privileges to the fullest extent.

For consumer goods, the import value of medicines and pharmaceutical products was highest and continuously increased each year. $40 \%$ of the medicines in Thailand were imported and the import value of medicines and pharmaceutical products from the EU accounted for $66 \%$ of total medicines and pharmaceutical product imports $[37,38]$. This can be explained by the fact that original medicines and pharmaceutical products were mostly researched and developed in companies in the EU, and they were also patented there. Therefore, Thailand - as a member of the WTO, and agrees to the Trade-Related Aspects of Intellectual Property Rights (TRIPs) agreement, which is an agreement on intellectual property rights that are related to trade - could not manufacture those products under patent restrictions and they were highly priced as a result. The import value of these products will also tend to be higher in the future since the number of elderly in Thailand is increasing and diseases change rapidly.

Regarding the types of Thai businesses that investors from the EU were interested in, during 2005-2012, the manufacturing industry was the industry that received the highest amount of foreign investment. In that 7-year time span, direct investment from the EU increased by 2.5 times. In 2012, EU investors invested 2 billion USD in manufacturing

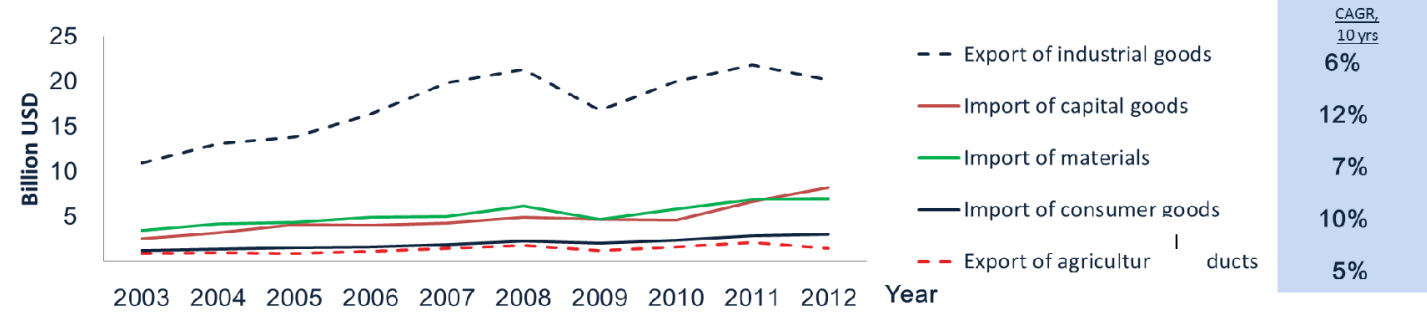

Figure 1: Import and export values between Thailand and the EU in the period from 2003-2012 Source: Bank of Thailand.

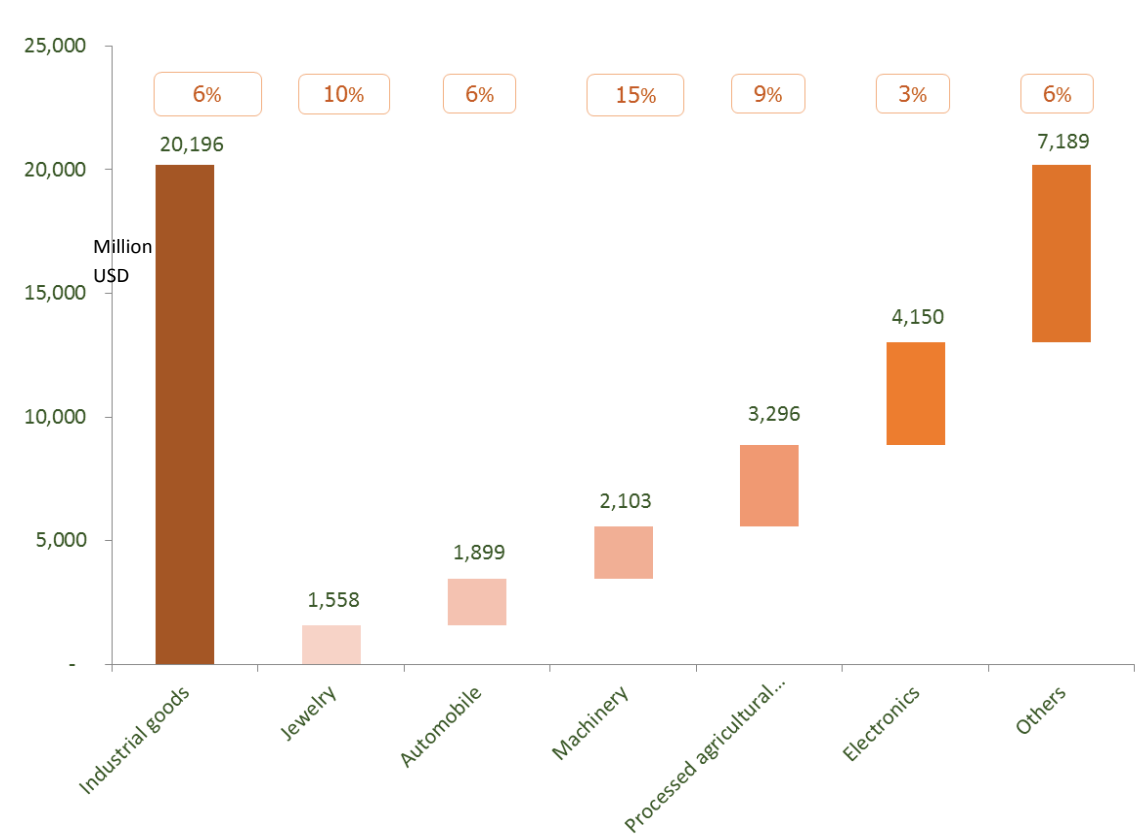

Figure 2: Top five export industries and their growth. 
Citation: Yamabhai I, Santatiwongchai B, Akaleephan C (2017) Assessing the Impact of the Thailand-European Union Free Trade Agreement on Trade and Investment in Thailand. Health Econ Outcome Res Open Access S1: 106. doi: 10.4172/2471-268x.1000.S1-106

Page 5 of 10

industry alone. Among the manufacturing businesses, the manufacture of computers, electronics and optical products received the highest foreign investment (676 million USD), followed by the manufacture of chemicals and chemical products (565 million USD). Financial and insurance activities as well as wholesale and retail trade were ranked second and third, respectively, in terms of foreign investments (539 and 375 million USD, respectively). There is also a category for investment in the manufacture of pharmaceutical products among the data from the Bank of Thailand. However, no investment in this category was found during this 7-year period.

\section{Increased cost to Thai exporters}

The top five products exported to the EU in 2012 were electrical machinery and equipment (HS85), agricultural and processed agricultural products (HS16 and HS40), machinery and computers (HS84), vehicles other than railway or tramway rolling stock (HS87), and precious stones and jewelry (HS 71). In total, these five categories accounted for $42 \%$ of the total export value from Thailand to the EU in that year.

From 2007 to 2012, the cost savings from the different tax rate between MFN rate and GSP rate, was around 29-52 million USD per quarter. For the fourth quarter in 2012, tax savings was 35 million USD. In fact, agricultural products saved the most from GSP at 84 million USD, while vehicles and automobile parts saved the least at around 11 million USD per year (Figure 3).
If those five product groups had used the MFN rate, the exporters or importers would have had to pay more on import duty by around 147 million USD per year. However, the statistics showed that the EU GSP was utilized for around $64 \%$ of the total exports value. Therefore, the impact of higher costs would have been smaller than estimated since not all exporters used the GSP eligibility.

\section{Determinants of Thai exports}

Tables 2 and 3 shows the determinants of Thai exports by taking into account supply and demand. Results show that the EU GDP has a strong and highly significant impact on exports in every model. For model 1 , it was seen that a tariff rate increase of $1 \%$ would decrease exports by $0.08 \%$ to $1 \%$. However, this variable is not statistically significant. Also, the relative competitive advantage compared with other ASEAN countries is positively correlated to exports. However, it is also not a significant determinant. Since the sample size was low due to the limited availability of data, the variable included in this model can only explain the variation by around $30 \%$.

\section{Experiences from countries where the EU FTA is already in place}

Export: Figure 4 illustrates a time series of the trends of export and import trade values, and exports to and imports from the EU. In terms of export value, after the FTA came into effect, every country seems to have increased its exports with the exception of South Korea, where exports slight decreased. From five years ago up to the current year of

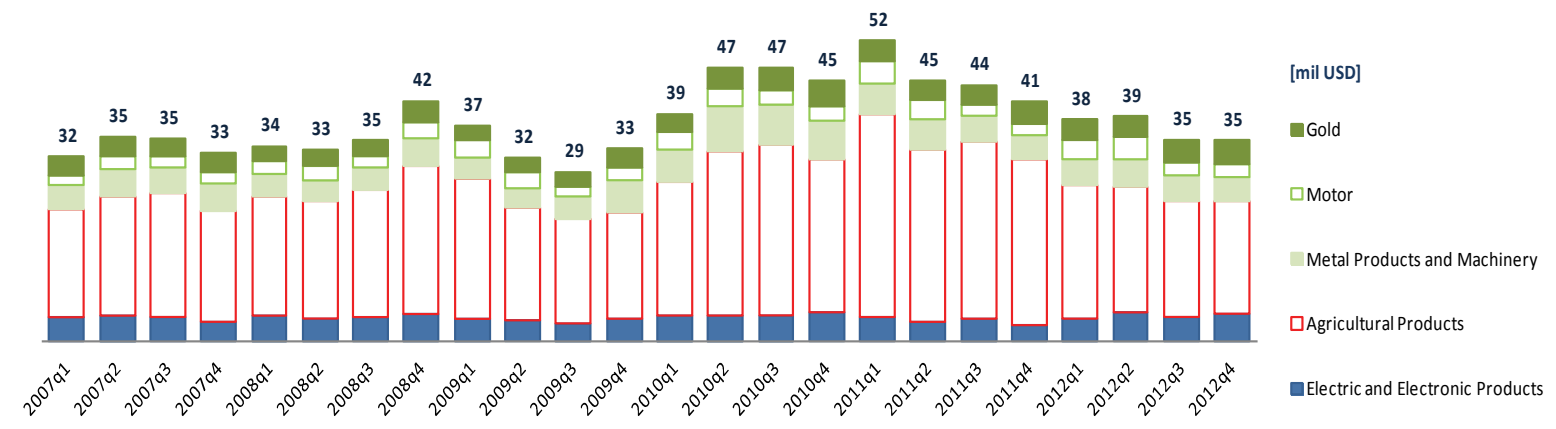

Figure 3: Import duty saved from GSP eligibility.

\begin{tabular}{|c|l|c|}
\hline Factors & \multicolumn{1}{|c|}{ Description } & Source of data \\
\hline InEXPG & National log of export value to EU (US Dollars) & Eurostat \\
\hline InEXPGS & National log of export value to EU (US Dollars) & Eurostat \\
\hline LnFDI & $\begin{array}{l}\text { Natural log of foreign direct investment stock from } \\
\text { EU (US Dollars) }\end{array}$ & Eurostat \\
\hline ER & $\begin{array}{l}\text { Natural log of exchange rate (the currency to US } \\
\text { Dollars) }\end{array}$ & World Bank \\
\hline GDP & Natural log of gross domestic product (US Dollars) & World Bank \\
\hline LEND & Lending rate (\%) & World Bank \\
\hline CPI & Consumer price index & World Bank \\
\hline PV & Political stability and absence of violence index & World Bank \\
\hline ROL & Rule-of-Law index & World Bank \\
\hline TEL & Number of telephone lines (per 1000 population) & World Bank \\
\hline EU27 & Dummy variable for EU 27 data (enforced=1) & \\
\hline FTA & $\begin{array}{l}\text { Dummy variable for years that the EUFTA has } \\
\text { (enforced = 1) }\end{array}$ & been enforced \\
\hline
\end{tabular}

Table 2: Factors included in the analysis of factors affecting exports from selected countries to the EU.

\begin{tabular}{|c|c|c|c|}
\hline \multirow{2}{*}{ Factors } & \multicolumn{3}{|c|}{ Export growth } \\
\cline { 2 - 4 } & $\mathbf{1}$ & $\mathbf{2}$ & $\mathbf{3}$ \\
\hline \multirow{2}{*}{ EU GDP growth } & $4.578^{\star *}$ & $4.469^{* *}$ & $4.154^{* *}$ \\
\cline { 2 - 4 } & -1.823 & -1.875 & -1.764 \\
\hline \multirow{2}{*}{ Tax rate } & -0.086 & -0.069 & -0.1 \\
\cline { 2 - 4 } & -0.259 & -0.271 & -0.247 \\
\hline \multirow{2}{*}{ RCA } & & 0.04 & \\
\cline { 2 - 4 } & & -0.127 & -0.013 \\
\hline \multirow{2}{*}{ Exchange rate } & & & -0.011 \\
\hline \multirow{2}{*}{ Constant } & & & -0.02 \\
\hline N & -0.019 & -0.018 & -0.024 \\
\hline R2 & -0.024 & -0.025 & 35 \\
\hline adj. R2 & 35 & 35 & 0.353 \\
\hline
\end{tabular}

Note: standard error in parentheses

${ }^{*} p<.1,{ }^{* *} p<.05,{ }^{* * *} p<.01$

Table 3: Determinants of export to the EU. 
Citation: Yamabhai I, Santatiwongchai B, Akaleephan C (2017) Assessing the Impact of the Thailand-European Union Free Trade Agreement on Trade and Investment in Thailand. Health Econ Outcome Res Open Access S1: 106. doi: 10.4172/2471-268x.1000.S1-106

the four countries that signed FTAs with the EU and the FTAs already entered into force, highlighted in yellow. Chile saw accelerated growth after 5 years from the year the FTA came into effect; the growth rate from the five years prior to the FTA coming into effect was $78 \%$, as opposed to $149 \%$ afterward.

Import: It can also be seen that every country increased the amount of import goods from the EU. However, Mexico and South Africa saw the growth rate in imports decrease after their FTAs came into effect. Before FTA was effective, Mexico's five-year growth rate was $113 \%$ and subsequently dropped to $49 \%$ for the five years after the FTA came into effect. South Africa also showed a decreasing growth rate from $75 \%$ to $45 \%$ of the growth from the period of 1995-2000 and 2000-2005, respectively. In terms of imports, only Mexico showed a decreasing growth rate while Chile and Mexico showed that the growth rate was 7 and 4 times compared to the pre-FTA era, respectively. Chile imported 3.3 million USD of goods from the EU in 1998 and increased to 3.7 million USD in 2003; the import value continued to increase significantly to 7 million USD in 2008.

Determinants of export to the EU: This section shows the empirical results based on pooled data for those four countries during 1995-2012. Three different econometric techniques were used, yielding six combinations of different variables used, as shown in models 1 to 6 . As expected and in line with previous literature, EU GDP and countries are highly significant with a positive sign. On the other hand, Interest rate and Inflation rate are negatively correlated with exports. For example, if the interest rate and inflation rate increase by $1 \%$, exports would decrease by around $0.03 \%$. The same amount of effect was seen in the exchange rate factor. The effect of exchange rate on exports is negatively significant at a $90 \%$ confidence level in models 3 and 5 only. Hence, the results show that after the FTA came into effect, it had a significant and negative impact on exports.

Trade in services: In the past 10 years, the EU had steadily been increasing the import and export of services from those four countries. For Chile, three years before the effective FTA date, service export growth was at $98 \%$ while the growth rate in the following three years from the effective date dropped to $24 \%$. Figure 5 shows that every country had a trade deficit for services and the magnitude of the deficit increased after FTA came into effect.

\section{Determinants of trade in services}

According to the regression results shown in Tables 4 and 5, the integration of the EU's 27 member countries and the EU GDP per capita positively affect trade in services. This means that if the average income increases by $1 \%$, the import of services from the EU would increase by $2.2 \%$ and the export of services to the EU would increase by $1.7 \%$. Although Internet usage (per 100 people) has a positive impact on trade and services, it is not a significant factor. One variable of interest in this case, FTA effective, was found to have a positive effect on imports from the EU and have negative effects on the export of services to the EU. However, this variable is also not statistically significant.

Foreign direct investment: Figure 6 shows the amount of investment that EU investors have allocated to the countries with FTAs already in place. The accelerating trends of FDI from 1995 to 2011 can be seen, and this is due to the increasing number of countries that joined the EU. Before 2000, there were 15 countries in the EU and ten more countries joined the EU after 2001, and two more countries joined in 2004 to make the membership 27 countries.

South Africa was found to be the country that received the highest amount of FDI from EU investors. In 2011, FDI increased by $402 \%$ compared to FDI in 2000 when the FTA came into effect. FDI was also seen to have increased in Chile at a value of $65 \%$ more than 2005's FDI figure. In South Korea, FDI has been increasing steadily, although there was no FTA

Table 6 shows the results of a panel data analysis of factors determining FDI. Although all these factors show the expected signs, some of them are not statistically significant. The $\mathrm{R}^{2}$ value of these two models is 0.91 , showing that factors employed in these models can explain the variation of FDI by around $91 \%$. The results appear to support the arguments that economic factors, GDP, and exchange rate are important. For example, if GDP increases by $1 \%$, FDI will increase approximately $3.6 \%$. The weakening of the local currency by $1 \%$ results in a higher investment by $1.4 \%$. In addition, of the increase in EU membership to 27 countries positively impacts FDI; this is significant at the 0.1 level.

Interestingly, the analysis found that the development of infrastructure and political situation are influential and positively correlated to FDI, although they are not statistically significant. For the

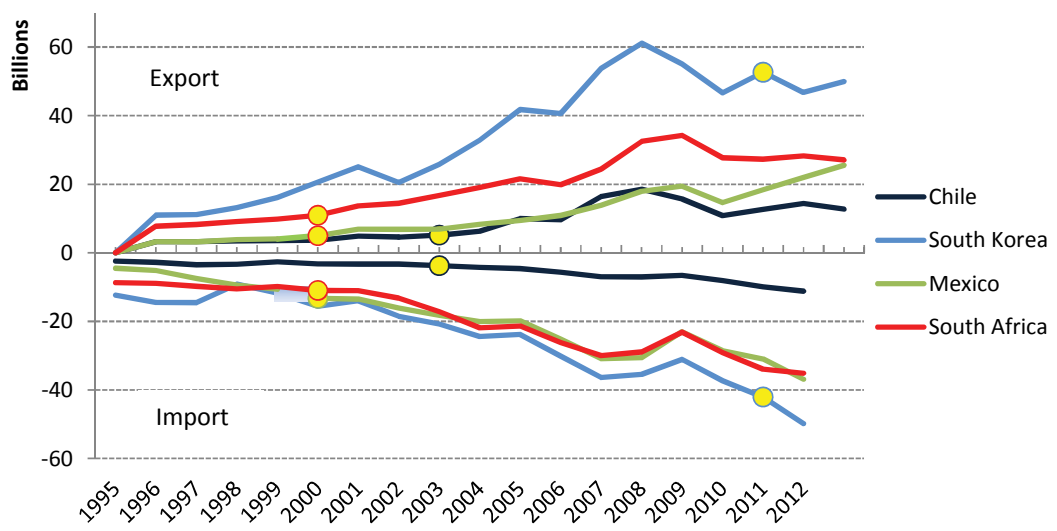

Note: represents effective year

Source: Eurostat

Figure 4: Trend of export and import goods between the four countries with EU FTAs and the EU. 
Citation: Yamabhai I, Santatiwongchai B, Akaleephan C (2017) Assessing the Impact of the Thailand-European Union Free Trade Agreement on Trade and Investment in Thailand. Health Econ Outcome Res Open Access S1: 106. doi: 10.4172/2471-268x.1000.S1-106

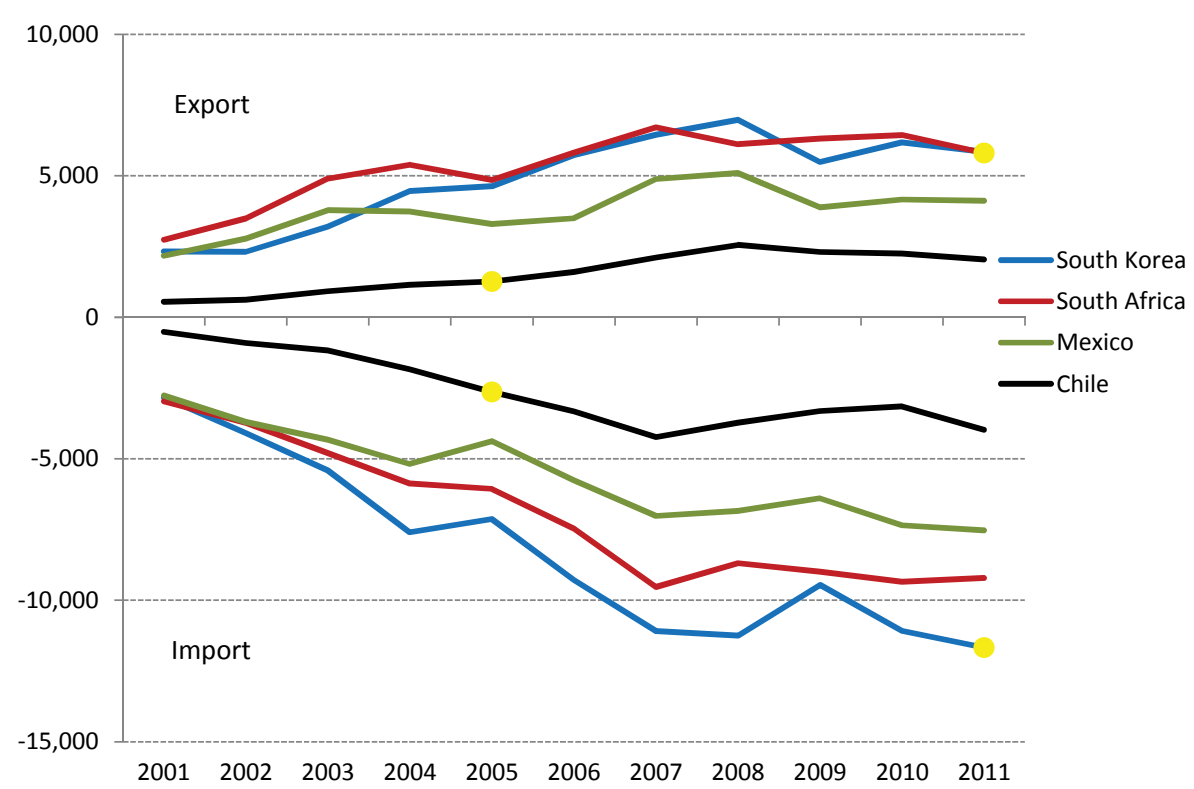

Source: Eurostat

Note: represents the year that the EU FTA came into effect

Figure 5: Trend of export and import of services between the four countries and the EU.

\begin{tabular}{|c|c|c|c|c|c|c|}
\hline & \multicolumn{2}{|c|}{ Random effect models } & \multicolumn{2}{|c|}{ Panel-corrected standard errors } & \multicolumn{2}{|c|}{ Time-fixed random effect models } \\
\hline \multirow{3}{*}{ Exchange rate } & -1 & -2 & -3 & -4 & -5 & -6 \\
\hline & -0.035 & -0.034 & $-0.035^{\star}$ & -0.034 & $-0.050^{*}$ & -0.051 \\
\hline & -0.028 & -0.03 & -0.02 & -0.023 & -0.03 & -0.033 \\
\hline \multirow{2}{*}{ Inflation rate } & $-0.035^{\star * *}$ & & $-0.035^{\star \star *}$ & & $-0.046^{\star * *}$ & \\
\hline & -0.011 & & -0.012 & & -0.013 & \\
\hline \multicolumn{2}{|c|}{ Interest rate } & $-0.023^{* *}$ & & $-0.023^{* *}$ & & $-0.032^{* * *}$ \\
\hline & & -0.009 & & -0.011 & & -0.011 \\
\hline \multirow{2}{*}{ EU GDP } & $3.358^{* * *}$ & $3.342^{* * *}$ & $3.358^{* * *}$ & $3.342^{* * *}$ & $2.954^{* * *}$ & $2.874^{* * *}$ \\
\hline & -0.399 & -0.424 & -0.37 & -0.406 & -0.633 & -0.683 \\
\hline \multirow[b]{2}{*}{ Country's GDP } & $0.271^{* * *}$ & $0.217^{* \star *}$ & $0.271^{* * *}$ & $0.217^{\star \star *}$ & $0.276^{\star \star *}$ & $0.205^{\star \star \star}$ \\
\hline & -0.065 & -0.065 & -0.057 & -0.052 & -0.069 & -0.07 \\
\hline \multirow{2}{*}{ FTA } & $-0.807^{\star * *}$ & $-0.843^{\star * *}$ & $-0.807^{\star * \star}$ & $-0.843^{* * *}$ & $-0.915^{\star \star *}$ & $-0.958^{* * *}$ \\
\hline & -0.162 & -0.168 & -0.186 & -0.196 & -0.18 & -0.19 \\
\hline \multirow{2}{*}{ _cons } & $-37.143^{* * *}$ & $-35.364^{* * *}$ & $-37.143^{\star * *}$ & $-35.364^{* * *}$ & $-30.384^{* * *}$ & $-27.091^{* *}$ \\
\hline & -6.03 & -6.641 & -5.497 & -6.362 & -9.819 & -10.857 \\
\hline $\mathrm{N}$ & 68 & 68 & 68 & 68 & 68 & 68 \\
\hline $\mathrm{R} 2$ & 0.74 & 0.73 & 0.74 & 0.73 & 0.78 & 0.78 \\
\hline
\end{tabular}

Table 4: Parameter estimates of the different models.

factor of particular interest, FTA, the analysis shows that after the FTA came into effect, it had a negative correlation to FDI. However, it is also not significant.

\section{Conclusion}

This study was conducted to demonstrate and estimate the likely impact on the Thai economy if Thailand agrees to sign an FTA with the EU by using the current situation and experiences from other countries. The role of the GSP on Thai exports to the EU is important; however, the impact is not as high as expected since Thai exporters have not maximized the privilege and the gap between the MFN tax and GSP tax is not dramatically significant [38].
Although there have been increasing trends on trade and investment in partner countries which signed FTAs with the EU after the FTA came into effect, this study failed to find empirical evidence to support the notion that an FTA has a positive impact on exports and FDI but instead found that economic variables have greater influence. This is in line with previous studies which found that GDP and GDP per capita are the significant determinants of trade and investment $[29,32]$. Slootmaekers also found that FTAs are not a significant determinant to export [14].

This study has some limitations. First, the sample size is very small. This is because the scope of the study focuses only Asian countries or low and middle income countries that have EU FTAs which were in effect. Therefore, only 4 countries were included. Although the bias was 
Citation: Yamabhai I, Santatiwongchai B, Akaleephan C (2017) Assessing the Impact of the Thailand-European Union Free Trade Agreement on Trade and Investment in Thailand. Health Econ Outcome Res Open Access S1: 106. doi: 10.4172/2471-268x.1000.S1-106

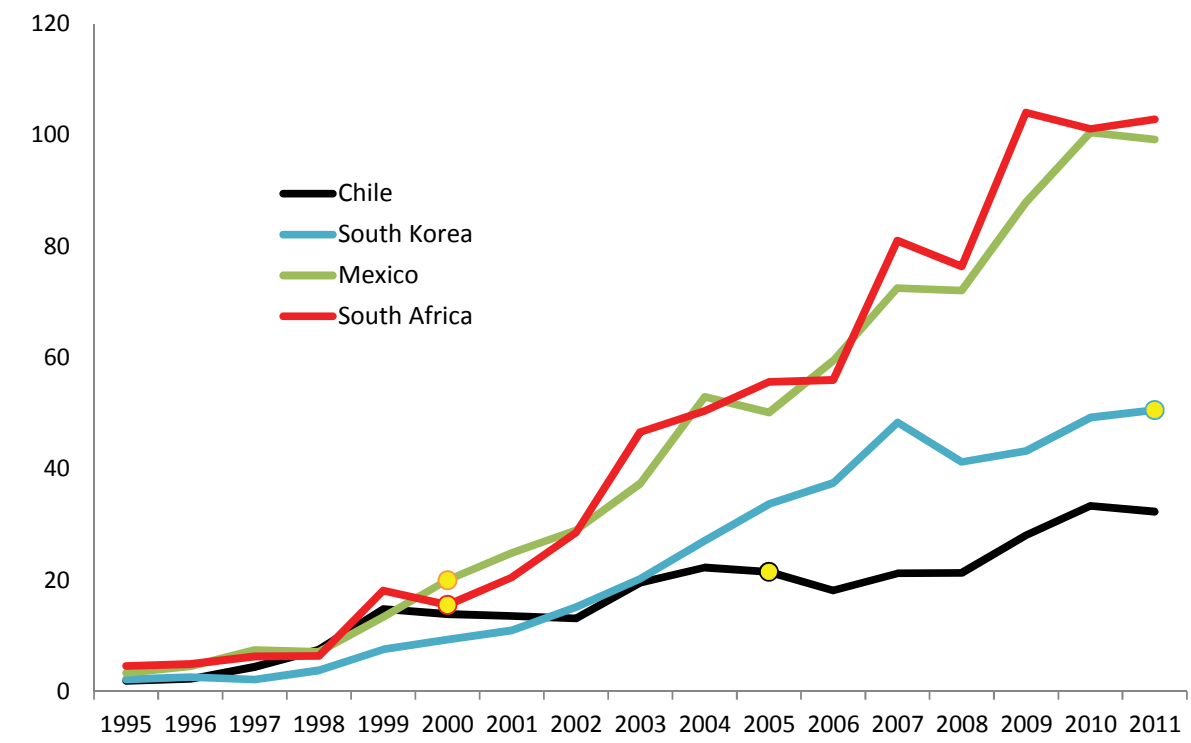

Sources: Eurostat and IMF

Note $\bigcirc$ Effective year of EU FTA

Figure 6: Trend of EU investments in the four countries.

\begin{tabular}{|c|c|c|}
\hline & $\begin{array}{c}\text { Services imported from } \\
\text { the EU (1) }\end{array}$ & $\begin{array}{c}\text { Services exported to the } \\
\text { EU }(3)\end{array}$ \\
\hline EU27 & $0.296^{\star * *}$ & $0.273^{\star * *}$ \\
\hline & $(0.074)$ & $(0.087)$ \\
\hline GDP per capita & $2.222^{\star \star *}$ & $1.728^{\star \star *}$ \\
\hline & $(0.512)$ & $(0.601)$ \\
\hline Internet use & $0.007^{*}$ & 0.001 \\
\hline & $(0.004)$ & $(0.005)$ \\
\hline FTA & 0.038 & -0.021 \\
\hline & $(0.084)$ & $(0.099)$ \\
\hline cons & 2.585 & 6.862 \\
\hline & $(4.358)$ & $(5.115)$ \\
\hline $\boldsymbol{N}$ & 44 & 44 \\
\hline $\boldsymbol{R}^{2}$ & 0.904 & 0.769 \\
\hline adj. $\boldsymbol{R}^{2}$ & 0.885 & 0.724 \\
\hline Hausman-test & 34.98 & 26.32 \\
\hline Model type & $(p<0.000)$ & $(p<0.01)$ \\
\hline
\end{tabular}

Table 5: Parameter estimates of the fixed effect models.

controlled, the small sample effect could affect the robustness of the results. Future studies should include other countries in their research to increase robustness.

Second, this study covers only tangible outcomes on trade and investment. The econometric models employed in this study might not be able to cover complex issues. For instance, the variable FTA used a dummy variable to represent the year that FTA came into effect. However, the effect on tax benefits might not happen right after the FTA comes into effect. Moreover, each country has a different transitional period. Some countries have a transitional period of 10 years to reach to zero import duty for most of their products $[16,39,40]$. Therefore, a future study should create the FTA variable that can accumulate the level of openness or benefit from duty obtained from the agreement and it can be varied from time to time to reflect the level of tax duties saved.

\begin{tabular}{|c|c|c|}
\hline \multirow{2}{*}{ Factors } & \multicolumn{2}{|c|}{ Fixed effect model } \\
\hline & (1) & (2) \\
\hline \multirow{2}{*}{ GDP } & $3.739^{* * *}$ & $3.624^{* * *}$ \\
\hline & $(0.562)$ & $(0.581)$ \\
\hline \multirow{2}{*}{ Exchange rate } & $1.450^{\star * *}$ & $1.554^{\star * *}$ \\
\hline & $(0.293)$ & $(0.289)$ \\
\hline $\begin{array}{l}\text { Number of fixed telephone lines per } \\
1,000 \text { population }\end{array}$ & $\begin{array}{c}0.019 \\
(0.017)\end{array}$ & $\begin{array}{c}0.007 \\
(0.016)\end{array}$ \\
\hline \multirow{2}{*}{ Political stability } & 0.281 & \\
\hline & $(0.238)$ & \\
\hline \multirow{2}{*}{ Rule of Law } & & 0.555 \\
\hline & & $(0.547)$ \\
\hline \multirow{2}{*}{ FTA } & -0.071 & -0.003 \\
\hline & $(0.174)$ & $(0.157)$ \\
\hline \multirow{2}{*}{ EU27 } & $0.334^{*}$ & $0.319^{*}$ \\
\hline & $(0.174)$ & $(0.173)$ \\
\hline \multirow{2}{*}{ _cons } & $-81.542^{\star \star *}$ & $-78.922^{* * *}$ \\
\hline & $(14.454)$ & $(14.901)$ \\
\hline$N$ & 52 & 52 \\
\hline$R^{2}$ (within) & 0.912 & 0.911 \\
\hline$\sigma_{u}$ & 5.855 & 0 \\
\hline$\sigma_{e}$ & 0.299 & 0.300 \\
\hline Hausman-test & $\begin{array}{c}120.23 \\
(p=0.000)\end{array}$ & $\begin{array}{c}113.42 \\
(p=0.000)\end{array}$ \\
\hline Model type & FEM & FEM \\
\hline
\end{tabular}

Table 6: Determinants of EU FDI.

Third, this study does not look at technical barriers. It has been seen that the EU has regulations where agricultural products exported to the EU must comply with environmental and chemical regulations. There are 9 measures implemented, which are 1) Sanitary and Phytosanitary Measures (SPS); 2) Genetically Modified Organisms (GMO); 3) Hazard analysis and critical control points (HACCP); 4) European System Related to Good Agricultural Practice (EUREPGAP); 5) Good Agriculture Practices (GAP); 6) Organic Foods labeling; 7) Packaging; 
Citation: Yamabhai I, Santatiwongchai B, Akaleephan C (2017) Assessing the Impact of the Thailand-European Union Free Trade Agreement on Trade and Investment in Thailand. Health Econ Outcome Res Open Access S1: 106. doi: 10.4172/2471-268x.1000.S1-106

Page 9 of 10

8) Plant Health; and 9) Health certification. It would be interesting to estimate the cost to Thai exporters that have to comply with these measures to get the holistic impact.

Experiences from other countries should also be investigated further. In particular, South Africa ran into problems with the EU after signing the FTA agreement. Specifically, the EU wanted South Africa to remove the words port and sherry on wine labels and requested for being able to fish near the African borders. South Africa agreed to change the label but did not agree to allow the EU to fish near the African borders. The EU was blamed that it only cared for its own economy and took advantage of countries with lower competitiveness. Later, the government of South Africa announced that they could not add any more requirements into the agreement [16]. These issues should be looked at in further detail to see what kind of requirements Thailand might face.

Currently, the EU has started trade negotiations at the regional level with the whole of the Central America. For example, the Association Agreement between the European Union and Central America (Costa Rica, El Salvador, Guatemala, Honduras, Nicaragua and Panama) was approved by the European Parliament on 11 December 2012. Benefits of the agreement will be particularly tangible for Central America's economy, which is expected to grow by over two and a half billion Euros annually once the agreement applies to the entire region. Also, the agreement with the Andean region, Colombia, and Peru, has been provisionally applied and it is likely to expand to Ecuador and Bolivia. In Asia, Singapore, Malaysia, and Vietnam have started negotiations but the agreements have not yet been concluded. Based in these negotiations, these countries will finally be competitive with the ones that signed EU FTAs. It will be interesting to see the impact of the EU FTA on every country that has ongoing negotiations, particularly who will be better off and how trade is affected.

Ultimately, an FTA aims to support trade and investment between countries. It could create opportunities for obtaining cheaper materials, and investing opportunities in countries where total costs are lower and which would benefit from technology spill-over effects. Free trade promotes competitiveness and the end customer will eventually receive benefits in the form of better goods and better prices. In other words, trade liberalisation targeted to the global supply chains of goods, services as well as investment. However, this is a theory that needs to be proven.

The information on benefit to partner countries or negotiating country is a prerequisite to the negotiating processes. Policy makers and negotiators with comprehensive data and information could make better negotiation and firm benefit to the country. This study has added on the retrospective information on the impact on EU FTA on countries' economic. Many policies can be implemented. First, given the GSP rate is not $100 \%$ utilised, the measures to stimulate or to remove barriers to use GSP. This is to maximize the benefit of the privilege. Second, according to trend in EU investors invested in Thailand, the pharmaceutical industry that Thailand needs technical and capital investment and there has been not much investment from $\mathrm{EU}$ investors. This sector can be used to develop the investment policy or to use as an issue to negotiate at the FTA.

In addition, all trade between countries would result in benefit to some issues and sectors on one hand and negative effects on the other hand, so countries in FTA negotiation should take the balance between both sides. On negative effect, countries, especially the developing countries would have measures to mitigate such effect while make use of the benefit efficiently. To balance the impact of FTA, other sectors beyond economics and industrial, i.e. societal and health sectors should be underlined to better understand the consequences of EU's trade policy choices.

Other issues in FTAs beyond tariff reduction and increasing market access in conventional trade in goods, services and investments should be considered. Due to the slow progress in WTO multilateral negotiation, many developed countries have been heading to bilateral and regional FTAs to developing countries with the policy on advancement of WTO Agreements or WTO Plus which are not consensual in the WTO negotiation. It was indicated that TRIPs Plus is one of such advancement which aim to increase and broader protection of the private rights in intellectual property, the patent term extension, for example. This issue will affect negatively countries' health and pharmaceutical sector, especially the developing countries without capacity in research and development and innovation.

In conclusion, when developing a trade negotiation, it is important to obtain retrospective and concurrent evidence from other countries prove the costs and benefits of an EU FTA rather than using perspective studies alone.

\section{Acknowledgements}

This study was funded by the International Trade and Health Programme under Country Cooperation Strategy 2012-2016 of the Collaboration between the Royal Thai Government (Health Systems Research Institute, National Health Commission Office, National Health Security Office, Ministry of Public Health and Thai Health Promotion Foundation) and the World Health Organization (WHO). The Health Intervention and Technology Assessment Program (HITAP) is supported by the Thailand Research Fund under the Senior Research Scholar on Health Technology Assessment (RTA5580010) and Thai Health Global Link Initiative Program (TGLIP), supported by Thai Health Promotion Foundation.

\section{References}

1. Pollet-Fort A (2011) The EU-Korea FTA and its Implications for the Future EUSingapore FTA. In EU in Singapore (Ed.).

2. Ministry of Commerce (2013) International Trade Statistics of Thailand.

3. Permanent Representative of Thailand to the WTO (2012) Impact of EU GSP Reform on Thai export

4. Department of Trade Negotiations (2010) Impact of Thai-EU FTA (21 Apr 2010 edn.).

5. Francois J, Norberg H, Thelle M (2007) Economic Impact of a Potential Free Trade Agreement (FTA) Between the European Union and South Korea.

6. Sarl I (2012) Evaluation of The Economic Impact of The Trade Pillar of The EuChile Association Agreement: the European Commission, Directorate Genera for Trade.

7. BBC (2012) Timeline: The Unfolding Eurozone Crisis

8. Chumacero R, Fuentes R, Schmidt-Hebbel K (2004) Chile's Free Trade Agreements: How Big is the Deal? Central Bank of Chile Working Papers.

9. Nowak-Lehmann F, Herzer D, Vollmer S (2007) The Free Trade Agreement between Chile and the EU: Its Potential Impact on Chile's Export Industry. Applied Econometrics and International Development 7.

10. Bureau JC, Jean S, Albagly M, Foster WE, Espinosa CF, et al. (2012) Evaluation of the Economic Impact of the Trade Pillar of the EU-Chile Association Agreement.

11. Jean S, Mulder N, Ramos MP (2012) A General Equilibrium, Ex-Post Evaluation of the EU-Chile Free Trade Agreement 41: 33-45.

12. European Commission (2013) Mexico - Trade - European Commission.

13. Villarreal MA (2012) Mexico's Free Trade Agreements.

14. Slootmaekers V (2004) Trade Effects of the EU-Mexico Free Trade Agreement.

15. Breuss F, Francois JF (2011) EU-South Korea FTA - Economic Impact for the EU and Austria. Policy Brief. 
Citation: Yamabhai I, Santatiwongchai B, Akaleephan C (2017) Assessing the Impact of the Thailand-European Union Free Trade Agreement on Trade and Investment in Thailand. Health Econ Outcome Res Open Access S1: 106. doi: 10.4172/2471-268x.1000.S1-106

16. Assarson J, Swain RB (2005) The Impacts of the European Union - South Africa Free Trade Agreement. Uppsala University.

17. Jachia L, Teljeur E (1999) Free trade between South Africa and the European Union: a quantitative analysis.

18. Kalaba M, Sandrey R, Seventer DEV (2005) Analysis of Trade between South Africa and the EU and a Preliminary Attempt to Examine the Impact of the EUSA FTA on Trade. Trade \& Industrial Policy Strategies (TIPS).

19. Gay SH, Nieuwoudtl WL (2000) Influences of the Free Trade Agreement between South Africa and the European Union on the South African Fresh Orange Industry. SAJEMS NS 3: 484-498.

20. ECORYS (2009) Trade Sustainability Impact Assessment for the FTA between the EU and the Republic of India. Rotterdam.

21. ECORYS, IIDE (2009) Trade Sustainability Impact Assessment for the FTA between the EU and ASEAN. Rotterdam.

22. Decreux $Y$, Mlitaritonna C (2007) Economic Impact of a Potential Free Trade Agreement (FTA) between the European Union and India.

23. Cramon-Taubadel SV, Hess S, Brümmer B (2010) A Preliminary Analysis of the Impact of a Ukraine-EU Free Trade Agreement on Agriculture. Policy Research Working Paper.

24. Nekhay O, Fellmann T, Gay SH (2012) A Free Trade Agreement between Ukraine and the European Union: Potential Effects on Agricultural Markets and Farmers' Revenues. Post-Communist Economies 24: 351-363.

25. CEPII-CIREM (2006) Economic Impact of a Potential Free Trade Agreement (FTA) Between the European Union and ASEAN.

26. Incorporated HWCT (2008) Study on ASEAN-EU FTA Impact on Thailand and Thailand's Strategy: Report 2 Costs and Benefits of an FTA to Thailand.

27. Bureau of Trade Preference. EU GSP: Department of Foreign Trade.

28. Kyereme SS (2002) Determinants of United States' Trade Balance with Australia. Applied Economics 34: 1241-1250.
29. Shane M, Roe T, Somwaru A (2008) Exchange Rates, Foreign Income, and U.S. Agricultural Exports. Agricultural and Resource Economics Review 37 160-175.

30. Botric V, Skuflic L (2006) Main Determinants of Foreign Direct Investment in the Southeast European Countries. Transition Studies Review 13: 359-377.

31. Çevis I, Çamurdan B (2007) The Economic Determinants of Foreign Direct Investment in Developing Countries and Transition Economies. The Pakistan Development Review 46: 285-299.

32. Delaunay C, Torrisi CR (2012) FDI in Vietnam: An Empirical Study of an Economy in Transition. Journal of Emerging Knowledge on Emerging Markets 4.

33. Kok R, Ersoy BA (2009) Analyses of FDI Determinants in Developing Countries International Journal of Social Economics 36: 105-123.

34. UNCTAD (1998): Host Country Determinants of Foreign Direct Investment. In World Investment Report 4.

35. Eurostat (2013) Client and Supplier Countries of the EU27 in Merchandise Trade from European Commission.

36. Department of Foreign Trade (2013) Utilization of Trade Preference of AFTAFTA-GSP. Trade Preference, Q4.

37. Department of Trade Negotiation (2009) Pharmaceuticals (HS30).

38. Department of Trade Negotiations (2555) New GSP of EU. International trade and economic analysis.

39. Tangkitvanich S (2009) Reaping Benefits from FTAs (Phase IV): ASEANEU Free Trade Agreement versus Partnership and Cooperation Agreement Thailand Development Research Institute.

40. Council Decision: Concerning the Provisional Application of the Agreement on Trade, Development and Cooperation between the European Community and Its Member States, of the One Part, and the Republic of South Africa, of the Other Part. (1999) 